\title{
Fatigue at Work: Scale Validation with Airline Pilots
}

\author{
Victor Rafael Rezende Celestino ${ }^{1^{*}}$ \\ Julia Sursis Nobre Ferro Bucher-Maluschke ${ }^{1}$ \\ Elaine Cristina Marqueze ${ }^{2}$
}

${ }^{1}$ Universidade de Brasília, Brasília, DF, Brazil ${ }^{2}$ Universidade Católica de Santos, Santos, SP, Brazil

Received 06 March 2019. This paper was with the authors for three revisions. Accepted 18 September 2020. First published online 06 October 2020.

Editor-in-chief: Carlo Gabriel Porto Bellini (iD)(Universidade Federal da Paraíba, João Pessoa, PB, Brazil)

Associate editors: Daniel Viana Abs da Cruz (D) (Universidade Federal do Rio Grande do Sul, Porto Alegre, RS, Brazil) and Carlo Gabriel Porto Bellini (DD (Universidade Federal da Paraíba, João Pessoa, PB, Brazil)

Reviewers: Alexsandro Luiz de Andrade (DD (Universidade Federal do Espírito Santo, Brazil) and Clarissa Socal Cervo (iD (Universidade Federal Fluminense, Brazil)

Editorial assistants: Kler Godoy and Simone Rafael (ANPAD, Maringá, PR, Brazil) 


\section{ABSTRACT}

In the organizational context, the study of occupational stress encompasses constructs of fatigue at work. Within the air transportation sector, fatigue at work is a potential issue influencing both safety and occupational stress. The objective of the present study was to perform a convergentdiscriminant validity analysis of the Feeling of Fatigue scale in the area of Administration. Data from an observational cross-sectional study involving a sample of 1,066 airline pilots were analyzed using quantitative modeling. Confirmatory factor analysis with the structural equations model was performed to determine the validity of a Portuguese version of the Feeling of Fatigue scale in the organizational context of civil aviation. This study fills a gap in the literature on occupational stress in Administration, highlighting the relevance of research on fatigue at work. The results confirmed the validity of a Portuguese version of a mature scale for subjective assessment of fatigue in Administration, thereby contributing to fatigue management in organizational settings.

Keywords: occupational stress; fatigue at work; feeling of fatigue; convergent-discriminant validity; civil aviation

JEL code: C30, I19, M19 


\section{INTRODUCTION}

Most research in Administration addresses stress and burnout, with the latter defined as a psychophysiological state of occupational exhaustion and incapacity to work (Monteiro, Pereira, Daniel, Silva, \& Matos, 2017; Vasconcelos, Vasconcelos, \& Crubellate, 2008). However, fatigue at work has received far less research attention in Administration journals, as evidenced by the dearth of studies found by the authors in a review of the relevant literature.

In the health sector, the impact of the recent pandemic on health workers has highlighted the need for further research investigating fatigue at work and burnout (Sasangohar, Jones, Masud, Vahidy, \& Kash, 2020) to better identify and study these related (yet different) constructs. Another organizational area concerned with fatigue at work is transportation, particularly the air transport sector. In this sector, fatigue is a potential issue in terms of both safety and occupational stress, largely in relation to the inherent intense work schedules (Drongelen, Boot, Hlobil, Beek, \& Smid, 2017).

A considerable proportion of workers (pilots) regularly report fatigue. This is partly the result of long irregular working days, crossing of time zones, and insufficient sleep opportunities (Drongelen et al., 2017). Research on the effects of shift work has focused mainly on physiological, psychosocial, and sleep health. However, few investigations have evaluated shift workers' personal experiences (Matheson, O'Brien, \& Reid, 2014). There is a particular need for more studies measuring the phenomenon of feeling of fatigue at work.

Feeling of fatigue can be a direct result of overexertion to achieve task objectives and assure performance levels during periods of higher workload. The feeling of fatigue has properties resembling a generalized background emotion, incorporating characteristics of other basic emotions (Hockey, 2013). Fatigue at work has been assessed using a variety of instruments (Gawron, 2016; Sagherian \& Brown, 2016; Winwood, Winefield, Dawson, \& Lushington, 2005). However, the Feeling of Fatigue scale (Yoshitake, 1971) is widely used for subjectively measuring this emotion (Matthews, Desmond, Neubauer, \& Hancock, 2018).

Against this background, the objective of the present work was to perform a convergentdiscriminant validity analysis of the Portuguese version of the Feeling of Fatigue scale among airline pilots. This study contributes by filling a gap in the field of fatigue in the workplace, emphasizing its relevance for Administration research and demonstrating the validity of a Portuguese version of the Feeling of Fatigue scale. There are few subjective instruments available for assessing fatigue in professions where it poses a major challenge, both in terms of the health of these professionals and enhancement of operational safety (Gander, Mangie, Phillips, SantosFernandez, \& Wu, 2018; Morris, Wiedbusch, \& Gunzelmann, 2018; Zaslona, O’Keeffe, Signal, $\&$ Gander, 2018), aspects also addressed by the present study. 


\section{THEORETICAL BACKGROUND}

\section{Fatigue at work}

Societal transformations in the workplace have led to studies on pleasure and mental suffering, together with their causes and consequences for work performance (Silva et al., 2015). Among the approaches reported in the literature, occupational stress considers that people have an ability to confront stimuli in an intermediate state between health and disease (Silva et al., 2015), requiring actions for individual and collective mental health management. A study of the occupational stress resulting from effects of different organizational variables showed that support from managers and colleagues at work (Monteiro et al., 2017) was more important than human resources services or the organizational culture. The mainstream belief holds that occupational stress is manageable by the organization and adaptable to the environment in which it operates. Another study explored the relationship between organizational stress-inducing practices and employee responses/performance, concluding that "stress in organizations is as complex as the level of stress in society: it will depend on the control of stress levels coming from society" (Vasconcelos et al., 2008, p. 48). Instead of serving as a management tool to induce behaviors, occupational stress can result in unforeseen organizational consequences, including risk of fatigue at work.

In a review of a century of research on occupational stress, the authors anticipated a future trend in which theory and research continue to develop toward gathering evidence for causal inference, through greater integration of psychophysiological data and work-life models (Bliese, Edwards, \& Sonnentag, 2017). Thus, this field of study should continue to seek theory and research that support applied knowledge in order to assist organizations in managing current and future stressors that may emerge in the next 100 years. Despite the importance of the theme, a bibliographical review of occupational stress literature published from 2010 to 2014 (Ferreira, Reis, Kilimnik, \& Santos, 2016) determining whether the topic continues to be investigated, how and where, found few papers in major Brazilian Administration journals (Ferreira et al., 2016). Occupational stress is important in Administration given its impact on health and well-being at work, which, in turn, can negatively affect performance, increase costs, and reduce the effectiveness of organizations.

The term 'occupational stress' has been employed in the literature with various different meanings (Hancock \& Desmond, 2001; Paschoal \& Tamayo, 2004). Within the broader concept of occupational stress, jobs in some sectors, such as transportation, medicine, and energy, still face the challenge of how to deal with occupational safety, particularly fatigue at work. The key issue tends to center on defining optimum conditions in which humans and technology can work together safely and sustainably (Nunes \& Cabon, 2015). Another bibliometric study reviewed 100 years of research in occupational safety, showing how this evolved from basic protections and job analysis to a systemic and multi-level view of safety and risk (Hofmann, Burke, \& Zohar, 2017). The study concluded that, although much progress has been made, too many injuries,

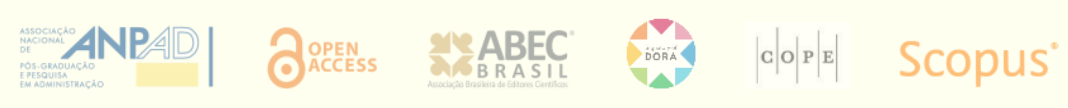


fatalities, and cases of occupational diseases still occur in the workplace. Thus, there is still much to be researched.

It is noteworthy that the concepts of fatigue and stress, due to a long history of use (in science, work, and by the general public), are often reported in the workplace as if their meaning is clear, overlooking the complexity involved (Sonnentag \& Frese, 2003; Tepas \& Price, 2001). Research has not only found differences, but also shown that fatigue and stress are multidimensional constructs that interact. Fatigue and stress states can occur simultaneously and are difficult to distinguish, but should not be considered synonymous (Gaillard, 2001; Glendon, Clarke, \& Mckenna, 2006). The ISO 10075-1 standard - Ergonomic principles related to mental workload. General terms and definitions - proposes the standardization of definitions related to occupational stress. For the purpose of this study, the definition for fatigue proposed below was adopted (ISO, 2017):

Fatigue (Mental): temporary impairment of mental and physical functional efficiency, depending on the intensity, duration, and temporal pattern of the preceding mental strain. Recovery from mental fatigue is achieved by rest rather than changes in activity. This reduced functional efficiency becomes apparent in feelings of tiredness, less favorable relationships between performance and effort, type and frequency of errors. The extent of this impairment is also determined by individual preconditions (online).

Fatigue should not be reduced to a single dimension, given that it entails aspects that are multidimensional, dynamically interdependent, and not fully correlated (Phillips, 2015). To study fatigue at work, from a systemic theoretical perspective, psychophysiological data must be collected to determine the boundary conditions for the lives of the individual and/or group, by modeling the complexity of relationships between constructs such as cognition, emotion, and action, which can be treated as subsystems. Thus, this system can be analyzed in terms of multiple physiological, neuropsychological, and socio-political aspects. Finally, the literature recommends that convergent-discriminant validation should be sought, based on models for analyzing the effect of fatigue precursors, such as stressors at work (Melan \& Cascino, 2014).

\section{Fatigue in the aviation work environment}

Worker (pilot) fatigue is a significant problem in modern aviation operations, mainly due to work shifts, variable journeys, desynchronization of circadian rhythm, and insufficient sleep, factors that are prevalent in both civil and military flight operations. The negative effect of fatigue has proven a contributory factor for errors and accidents (Caldwell et al., 2009). Within aviation and other safety-critical fields, such as transportation, medicine, and energy, fatigue risk management systems (FRMS) represent a novel regulatory approach that combines advances in understanding of worker fatigue and factors that contribute to accidents, as well as advancements in safety management (Gander et al., 2011). FRMS work on the basis of data and the combination of scientific and operational knowledge, including processes for monitoring safety performance and for continuous improvement.

Prescriptive limits on working hours are familiar to shift workers, but these are more suited to circumstances of low-risk safety-related fatigue. However, economic needs have placed pressure
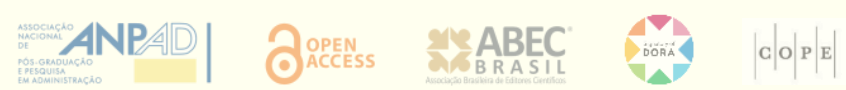
on a society with $24 / 7$ shift workers requiring more customized and flexible approaches to fatigue management, such as FRMS (Gander, 2015). Although the implementation of FRMS is growing in aviation, there is still little consensus on which constructs and associated safety performance indicators should be measured (Gander et al., 2014). Initiatives are scarce in both academia and industry, with insufficient results to draw any meaningful conclusions about a safe or unsafe condition from the indicators measured. Thus, a relative comparison of indicators, analyzed based on different operational contexts, is necessary to allow compilation of a database on psychobiological and operational factors and foster cooperation in the global effort to standardize acceptable indicators.

In order to manage fatigue responsibly, decisions cannot be based on a single measurement or sole technology to determine an absolute safety value. Human fatigue risk management systems should instead adopt a comprehensive approach (Mallis \& James, 2012). Evidence-based nonprescriptive approaches to fatigue management are needed in aeronautical operations (Mallis, Banks, \& Dinges, 2010). Therefore, an FRMS must be multi-layered and utilize multiple risk identification methods and risk reduction controls (Gander et al., 2011; Lerman et al., 2012). There is growing evidence that subjective assessments can serve as an effective, efficient, and costeffective tool in managing fatigue-related risk. Such assessments, however, should be based on a validated instrument and always be used as part of a more comprehensive FRMS (Smith, Browne, Armstrong, \& Ferguson, 2016).

The reliable use of subjective assessments in FRMS depends on a just culture, where individuals are encouraged and supported in reporting fatigue and elevated impairment (Darwent, Dawson, Paterson, Roach, \& Ferguson, 2015). Within a system such as FRMS, all stakeholders should be made aware of contributing factors that might affect their performance, through a system design able to capture and utilize the information from these reports. A recent systematic literature review (Bendak \& Rashid, 2020) concluded that risk associated with fatigue in aviation is diverse and ambiguous in nature. This study also revealed that many aspects related to this risk have not yet been fully investigated, and therefore further research identifying mitigation strategies for this risk is warranted.

\section{Subjective measures of fatigue}

The use of subjective measures of fatigue has been restricted mainly to laboratory-based methodologies (Smith et al., 2016), producing satisfactory results. A simulated field study showed that, at a group level, subjective assessments of fatigue correlated with objective performance, but that subjects' ability to predict performance varied significantly, both across conditions and between individuals (Smith et al., 2016). As expected, variation in fatigue tolerance was identified (Van Dongen, Maislin, \& Dinges, 2004). In particular, individuals with higher objective performance were worse at predicting their performance than those with lower objective performance. Two possible explanations have been proposed (Smith et al., 2016), whereby either weak correlations between objective and subjective assessments occur due to the range of the objective performance measure (less variability due to fatigue) or some individuals have an optimism bias and underestimate their impairment. The fact that individuals with some degree

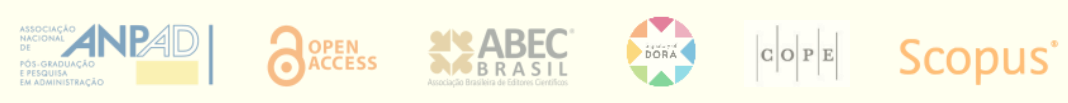


of tolerance to fatigue may be more confident in their resilience has major implications for fatigue risk management. This should be expected because such individuals may be unaware of their performance decline and may be unwilling to admit any fallibility due to professional and social pressures (Smith et al., 2016).

Fatigue at work has been assessed using a range of instruments (Gawron, 2016; Sagherian \& Brown, 2016; Winwood et al., 2005). Although internationally there are few validated scales available, "it is clear that there is no gold standard for fatigue assessment" (Aghdam, Alizadeh, Rasoulzadeh, \& Safaiyan, 2019). Of the fatigue assessment instruments available, the Feeling of Fatigue scale (Yoshitake, 1971) stands out for measuring subjectivity of this emotion. The scale was developed in 1969 by the Research Committee on Industrial Fatigue of the Japan Society of Occupational Health. It has since been applied to workers from a variety of sectors and countries (Chang, Sun, Chuang, \& Hsu, 2009). Unfortunately, most publications on the Feeling of Fatigue scale, including its originally validation (Saito, 1982), were published in Japanese only.

The Feeling of Fatigue scale (Yoshitake, 1971) consists of a checklist of 30 items that explore the presence of symptoms, classified into three groups of fatigue symptoms (Yoshitake, 1978): (a) drowsiness and dullness, (b) lack of ability to concentrate, and (c) projection of physical discomfort. Generally, the higher the number of symptoms, the greater the feeling of fatigue. Both $\mathrm{A}$ and $\mathrm{C}$ symptom sets are physical, with A 'general' and C 'specific (sensory and neuronal).' $\mathrm{B}$ symptoms are purely mental. Of the $\mathrm{A}, \mathrm{B}$, and $\mathrm{C}$ symptoms, the strongest correlation with feeling of fatigue is found for B. Because these symptoms do not exist independently and are mutually related, a multifactorial construct was originally proposed.

In the first study, involving 170 office workers (Yoshitake, 1971), each symptom was evaluated on a Likert scale for the presence or absence of the symptom, and not only with 'yes' or 'no' answers, as was implemented in a subsequent study. The latter study confirmed the three-factor Feeling of Fatigue scale through a comprehensive field study assessing subjective symptoms of fatigue at work in 17,789 workers on 250 occasions (Yoshitake, 1978). The labor activities evaluated included both physical (in several industries) and mental (pilots, train drivers, drivers, factory operators, at offices, researchers) work during different shifts (day, night, and shift work).

The internal structure of the three-factor Feeling of Fatigue scale was validated originally in Japan (Saito, 1982) among railway workers. The workers were assessed before and after work shifts for different schedules. Results showed that B symptoms were also associated with motivation. The content of the Feeling of Fatigue scale has been validated for use in Latin America (Almirall \& Reyes, 1982), where it has been consistently applied (Barrientos-Gutierrez, Martinez-Alcantara, \& Mendez-Ramirez, 2004; Parody, Viloria, Hernandez, Niño, \& Cervera, 2020). In the 1990s, Prof. Dr. Frida Fischer translated the Feeling of Fatigue scale into Brazilian Portuguese as part of her habilitation thesis (Privatdozent German Degree) (Fischer, 1990). Although the version was not formally validated, it has since been used in Brazil for several studies on fatigue at work (Metzner \& Fischer, 2001; Metzner, Fischer, \& Nogueira, 2008; Vasconcelos, Fischer, Reis, \& Moreno, 2011). 


\section{MATHERIAL AND METHODS}

\section{Instrument}

The Feeling of Fatigue scale (Yoshitake, 1971) is composed of three constructs (latent variables), each with 10 items measuring the presence of fatigue symptoms: FFA01-10 (drowsiness and dullness), FFB11-20 (lack of ability to concentrate), and FFC21-30 (projection of physical discomfort). The scores of the three latent variables (A, B, and C) are referred to as feelings of fatigue A, B, and C, denoted FFA, FFB, and FFC, respectively. The overall score of the 30 items is denoted FFS. Figure 1 depicts the instrument structure. Table 1 shows the instrument together with a proposed symptoms checklist in English (Yoshitake, 1971) and the translated version in Portuguese (Fisher, 1990) used in Brazil since 1990 by several studies, as outlined in section 'Subjective measures of fatigue'. Each indicator is assessed on a Likert scale with values ranging from 1 to 5 , where respondents answer the question 'how often do you present the following symptoms?' by choosing one of the following alternatives: 'never,' 'rarely,' 'sometimes,' 'many times,' or 'always.'

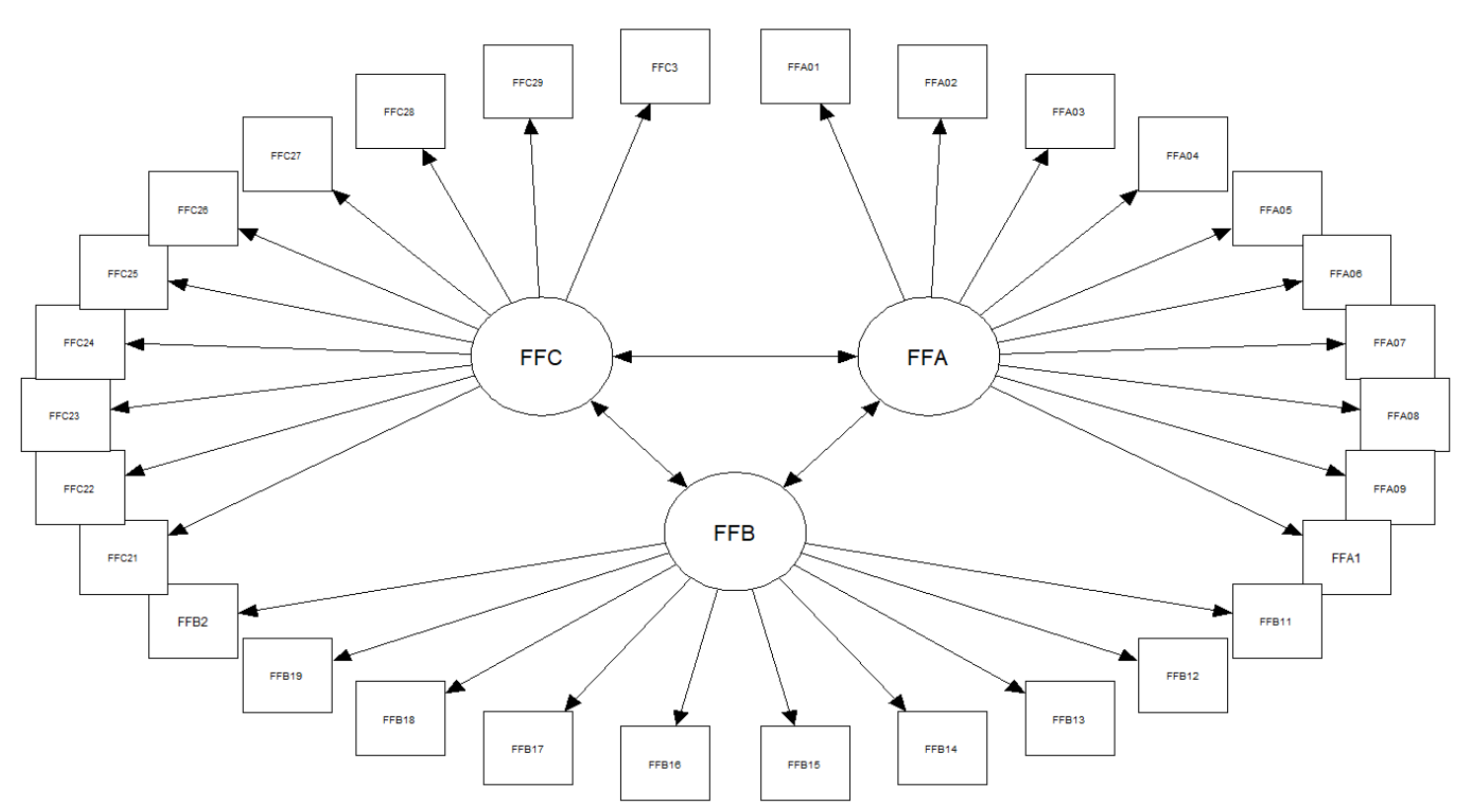

Figure 1. Feeling of Fatigue scale structure.

Developed by the authors based on Yoshitake, H. (1971). Relations between the symptoms and the feeling of fatigue. Ergonomics, 14(1), 175-186. https://doi.org/10.1080/00140137108931236 
Table 1

\section{Symptoms checklist of Feeling of Fatigue scale}

\begin{tabular}{|c|c|c|}
\hline Variable & English & Portuguese \\
\hline FFA01 & Feel heavy in the head & Sinto a cabeça pesada \\
\hline FFA02 & Feel tired in the whole body & Sinto moleza no corpo \\
\hline FFA03 & Feel tired in the legs & Sinto moleza nas pernas \\
\hline FFA04 & Give a yawn & Tenho vontade de bocejar durante o trabalho \\
\hline FFA05 & Feel the brain hot or muddled & As minhas ideias não são claras \\
\hline FFA06 & Become drowsy & Estou com sonolência \\
\hline FFA07 & Feel strained in the eyes & Sinto os olhos cansados \\
\hline FFA08 & Become rigid or clumsy in motion & Tenho dificuldade em me movimentar \\
\hline FFA09 & Feel unsteady while standing & Tenho dificuldades em me manter em pé \\
\hline FFA10 & Want to lie down & Eu gostaria de ir me deitar um pouco (durante o horário de trabalho) \\
\hline FFB11 & Find difficulty in thinking & Preciso me concentrar mais \\
\hline FFB12 & Become weary while talking & Não tenho vontade de falar com ninguém no trabalho \\
\hline FFB13 & Become nervous & Fico irritado(a) facilmente \\
\hline FFB14 & Unable to concentrate attention & Não consigo me concentrar bem \\
\hline FFB15 & $\begin{array}{l}\text { Unable to have interest in } \\
\text { thinking }\end{array}$ & Tenho que pensar outras coisas além do meu trabalho \\
\hline FFB16 & Become apt to forget things & Minha memória não está boa para o trabalho \\
\hline FFB17 & Lack of self-confidence & Cometo pequenos erros no meu trabalho \\
\hline FFB18 & Anxious about things & Tenho outras preocupações fora meu trabalho \\
\hline FFB19 & $\begin{array}{l}\text { Unable to straighten up in } \\
\text { posture }\end{array}$ & $\begin{array}{l}\text { Eu gostaria de estar em boa forma física para o meu trabalho, mas não } \\
\text { me sinto em condições }\end{array}$ \\
\hline FFB20 & Lack patience & Não posso mais continuar a trabalhar, embora tenha que prosseguir \\
\hline FFC21 & Have a headache & Sinto dor de cabeça \\
\hline FFC22 & Feel stiff in the shoulders & Ombros pesados \\
\hline FFC23 & Feel a pain in the waist & Dores nas costas \\
\hline FFC24 & Feel constrained in breathing & Dificuldades em respirar \\
\hline FFC25 & Feel thirsty & Boca seca \\
\hline FFC26 & Have a husky voice & Voz rouca \\
\hline FFC27 & Have dizziness & Tonturas \\
\hline FFC28 & Have a spasm of the eyelids & Tremores nas pálpebras \\
\hline FFC29 & Have a tremor in the limbs & Tremores nos membros (braços e pernas) \\
\hline FFC30 & Feel ill & Sinto-me doente \\
\hline
\end{tabular}

\section{Study design}

Adopting a deductive epistemological approach drawing on the theoretical background presented, we did a quantitative modeling study (Cauchik-Miguel et al., 2018; Creswell, 2014) to test the convergent-discriminant validity of the Feeling of Fatigue scale. We collected data by a cross-sectional observational study (Breakwell, Smith, \& Wright, 2012; Fontelles, Simões, Farias, $\&$ Fontelles, 2009) carried out as part of a larger study on Chronic fatigue, working conditions, and health of Brazilian pilots (Marqueze, Diniz, \& Nicola, 2014) in a Brazilian sample.

\section{Study population and sample}

The target population of the larger study comprised 2,350 regular aviation pilots, members of the Brazilian Association of Civil Aviation Pilots (Abrapac). Of this total, 1,234 answered an online questionnaire, representing $52.5 \%$ of the study population. Initially, the sample size was calculated ( $\mathrm{G}^{*}$ Power) to meet the objectives of the larger study Chronic fatigue, working conditions, 
and health of Brazilian pilots (Marqueze et al., 2014), in which the primary outcome was fatigue and sample power was $99 \%$. Of the overall total of 1,234 pilots, most participants $(97.1 \%)$ were male and average age of the pilots was 39.1 years ( $\mathrm{SD}=9.8$ years). Most of the respondents were captains $(57.9 \%)$, and the others were co-pilots/first officers (42.1\%). In terms of pilots' personal profile, $84.3 \%$ had a marital partner and $61.3 \%$ did not have children younger than 12 years. The average number of persons who contributed to family income was $1.6(\mathrm{SD}=0.7)$. Most pilots $(82.4 \%)$ were attending or had already completed college education. Of the sample, $53.7 \%$ did not reside near their primary work base, requiring long commutes between residence and base.

The professional environment reported indicated that mean time practicing as a pilot was 15.2 years $(\mathrm{SD}=10.1$ years $)$ and mean time engaged with the current airline was 5.8 years $(\mathrm{SD}=4.8$ years). The type of time off varied among pilots, but $27.6 \%$ usually had a single day off per week. A high percentage of pilots reported frequent or constant delays due to operational, maintenance, and dispatch issues (40.7\%). Most pilots (91.2\%) were predominantly flying domestically with basic crews. Pilots flew for an average of 65 hours monthly. The work shifts of almost all pilots (94.1\%) were irregular and involved night shifts (from 10 p.m. to 5 a.m.). Working hours were longest during the day shift (typically with early starts before $6 \mathrm{a} . \mathrm{m}$.), followed by the afternoon shift (with late finishes after 10 p.m.) and night shifts (usually starting before 10 p.m.). Finally, regarding working conditions potentially associated with increased fatigue, main factors reported by pilots were long working hours, number of flying hours, short rest periods between work shifts, and working night shifts (Marqueze, Nicola, Diniz, \& Fischer, 2017).

After the application of inclusion and exclusion criteria, 1,066 pilots remained in the present study sample, representing a large proportion of the overall pilot population in Brazil. The effort involved in achieving this sample size was considerable, as this population is usually averse to research surveys. Similar, more recent, attempts have failed to enroll more than a few dozen respondents. As operational conditions have not changed greatly since 2014, this data remains valid for the analysis performed.

Pilots actively working and flying with airlines at the time of the study, of both sexes, who were members of the Abrapac, were invited to participate in the study. Executive aviation, cargo, and air taxi pilots were excluded. Respondents with missing data on the Fatigue Scale were also excluded. A total of 168 cases with missing data (13.6\%) were excluded.

\section{Data collection}

After confirmation of the adequacy of the questionnaire via pilot testing conducted with Abrapac's Board of Directors (Brazilian aviation captains or co-pilots), invitations were sent out for participation in the study. Data were collected using a free online questionnaire tool, from December 2013 to March 2014. To avoid duplicate responses, individual emails were sent out. Questionnaire completion time was around 40-60 minutes. The data collection instrument contained questions gathering information on sociodemographics, work, health, lifestyle, and sleep variables used in the present study. The study evaluated the Feeling of Fatigue scale

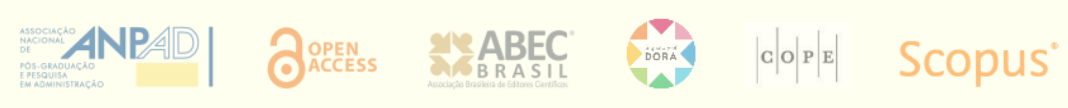


(Yoshitake, 1971) and sociodemographic variables (age, sex, and job position) as multiple groups for cross-validation.

Ethical aspects related to research involving humans were duly observed and all participants signed a Consent Form (Resolution 466/12 of the National Health Council). The study was supported by the Abrapac and approved by the Ethics Committee of the Federal Institute of Education, Science, and Technology of São Paulo (Opinion No. 625.158 / CET-IFSP).

\section{Data analysis}

The American Psychological Association (APA) standards for educational and psychological testing specify that evidence of validity based on internal structure be obtained by several statistical methods to evaluate the dimensionality, invariance of measurement, and reliability of an instrument (Rios \& Wells, 2014). The statistical method employed in this study was structural equations modeling (Bido, 2019; Gana \& Broc, 2018; Hair, Black, Babin, \& Anderson, 2009) for convergent-discriminant validation analysis (Campbell \& Fiske, 1959; Hair et al., 2009; Hutz, Bandeira, \& Trentini, 2015; Pasquali, 2007). The structural equations models (SEM) and associated analysis were performed using $R$ language version 3.6.1 (R Core Team, 2019) with $R$ Studio (R Studio Team, 2019) and the lavaan package (Bido, 2019; Gana \& Broc, 2018; Rosseel, 2012).

Respondents whose standardized fatigue score exceeded three standard deviations $(Z<-3$ or $>3)$ (i.e., outliers) were first identified (Cousineau \& Chartier, 2010; Hair et al., 2009). The latent variables FFA, FFB, and FFC were incorporated in a recursive reflexive measurement model (Bido, 2019; Gana \& Broc, 2018; Hair et al., 2009) with multiple groups represented by the sociodemographic variables assessed (age group, sex, job position). The measurement model with the lavaan code (Bido, 2019; Gana \& Broc, 2018; Rosseel, 2012) is shown in Table 2. The symbol "= " denotes a reflexive model, where the exogenous latent variables on the left explain the variances of the endogenous variables (indicators) on the right side of the measurement model equations (Bido, 2019).

Table 2

\section{Feeling of Fatigue scale - measurement model}

$$
\begin{aligned}
& \mathrm{FFA}=\sim \mathrm{FFA} 01+\mathrm{FFA02}+\mathrm{FFA03}+\mathrm{FFA04}+\mathrm{FFA05}+\mathrm{FFA06}+\mathrm{FFA07}+\mathrm{FFA08}+\mathrm{FFA09}+\mathrm{FFA} 10 \\
& \mathrm{FFB}=\sim \mathrm{FFB} 11+\mathrm{FFB} 12+\mathrm{FFB} 13+\mathrm{FFB} 14+\mathrm{FFB} 15+\mathrm{FFB} 16+\mathrm{FFB} 17+\mathrm{FFB} 18+\mathrm{FFB} 19+\mathrm{FFB} 20 \\
& \mathrm{FFC}=\sim \mathrm{FFC} 21+\mathrm{FFC} 22+\mathrm{FFC} 23+\mathrm{FFC} 24+\mathrm{FFC} 25+\mathrm{FFC} 26+\mathrm{FFC} 27+\mathrm{FFC} 28+\mathrm{FFC} 29+\mathrm{FFC} 30
\end{aligned}
$$

Note. Developed by the authors based on Bido, D. S. (2019). Modelagem de equações estruturais: Uma visão aplicada para a engenharia. In P. A. Cauchik-Miguel (Ed.), Metodologia científica para engenharia (pp. 81-108). Rio de Janeiro: Elsevier Brasil; and based on Yoshitake, H. (1971). Relations between the symptoms and the feeling of fatigue. Ergonomics, 14(1), $175-186$. https://doi.org/10.1080/00140137108931236

Convergent validity is obtained when indicators of a construct converge and share a large proportional of common variance (Hair et al., 2009). The first indicator involves standardized factor loadings (ideally $>0.5$ ) after confirmatory factor analysis (CFA) using structural equation 
modeling (SEM). Another metric is derived from average extracted variance (preferably $>0.5$ ). Finally, reliability measures $>0.6$ should be attained for convergent validity (Hair et al., 2009).

When comparing different instruments for discriminant validity, each construct should be unique and capture phenomena not measured by the others (Hair et al., 2009). Discriminant validity can be assessed by two criteria: Fornell-Larcker (Fornell \& Larcker, 1981) or HeterotraitMonotrait (HTMT) ratio of correlation (Henseler, Ringle, \& Sarstedt, 2015). The Fornell-Larcker criterion is based on the comparison of the square of the correlations between one construct and all others and the average variance extracted (AVE) by the construct. The HTMT criterion evaluates the ratio of the correlation between two constructs to the square root of the product of the reliability of the two latent variables. A cut-off of 0.85 is proposed in the literature for HTMT (Voorhees, Brady, Calantone, \& Ramirez, 2016), below which discriminant validity is shown. For discriminant validity, indicators should be related to a single latent variable without cross-loadings (Hair et al., 2009). In the present study, discriminant validity was assessed based on these two criteria for the three latent variables comprising the multifactorial Feeling of Fatigue scale (FFA, $\mathrm{FFB}$, and FFC). Correlations were measured and comparisons against AVE and reliability were analyzed for each pair. Given that all three latent variables measure aspects of the feeling of fatigue (Yoshitake, 1971), discriminant validity is expected to be rejected.

In this study, group comparisons were also performed to show cross-validation. Loose crossvalidation and loadings equivalence procedures (Hair et al., 2009) were applied. The former procedure verified that loadings, correlations between latent variables, and error variances (uniqueness) were similar for both groups. For the latter, non-standardized loadings are forced to be equal in both groups for model estimation and the difference in the chi-square statistic is evaluated. Other measures of fit were also determined.

In accordance with literature guidelines (Graham, 2006; Raykov, 1997a, 1997b), congeneric, tauequivalent, and parallel measurement models were also considered to assess for adequate compromise among internal consistency, reliability, and parsimony. Of the models evaluated, this study sought to validate the first order trifactorial model as that which best expressed the internal structure of the Feeling of Fatigue scale. To evaluate the fit quality of the measurement model, based on literature guidelines (Hooper, Coughlan, \& Mullen, 2008), the chi-square statistics, degrees of freedom and $\mathrm{p}$ value, comparative fit index (CFI), root mean square error of approximation (RMSEA), standardized root mean square residual (SRMR), and the Akaike information criterion (AIC) were employed to assess parsimony between alternative models. These indices were selected over others because they have proven less sensitive to sample size, erroneous model specification, and parameter estimation (Hooper et al., 2008).

Recommended standards to evaluate cut-off values for these quality indicators can be found in the literature. In this study, the recommendations proposed by Hair, Black, Babin and Anderson and Black (2009) were adopted. Even for very large samples and many variables, chi-square statistics should yield significant values to reject the null hypotheses that the estimated model resembles the measured covariance (Hair et al., 2009). Therefore, the fact that the chi-square statistic is not usually significant is irrelevant, especially when the analysis needs to consider a

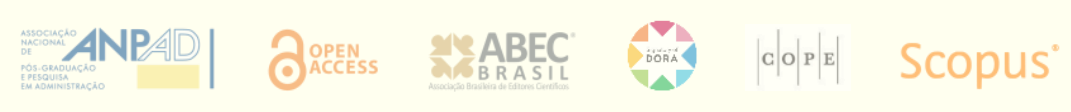


distribution that violates the normality assumption, usual and acceptable for a Likert scale (Norman, 2010). CFI values $>0.92$ are sought, while RMSEA and SRMR should be $<0.08$ (Hair et al., 2009).

\section{RESULTS}

\section{Convergent validity of internal structure of constructs}

The preliminary step was the removal of outliers. As the lowest standardized fatigue score was -2 , only participants with Z > 3 were excluded. Although only six outlier scores (observations 347, 484, 681, 704, 890, 1057) existed for the aggregated Feeling of Fatigue score (FFS), a total of 18 observations were excluded, including additional outliers for $\operatorname{FFA}(547,775)$, $\operatorname{FFB}(50,306,921)$, and FFC (192, 228, 301, 597, 694, 708, 905).

The relevant variables for the final sample of 1,048 pilots are described in Table 3, with the analysis of variance indicating significant mean differences between groups ( $\mathrm{p}$-value <0.05).

The next stage entailed the assessment of the measurement model. As initial assessments showed inadequate fit measures, modification indices were introduced by adding correlations between indicators that were related only to the same latent variable in order to avoid cross-loadings. Although some indicators with poor loadings could have been eliminated in order to improve the model, this approach was rejected for two main reasons. First, the validated version of the scale contained all indicators. Secondly, the Bartlett sphericity test and Keiser-Meyer-Olkin test for sample adequacy (Hair et al., 2009) showed that the three scales with all indicators had acceptable values.

Table 3

Sample description — relevant variables

\begin{tabular}{|c|c|c|c|c|c|c|c|c|c|}
\hline \multirow[b]{2}{*}{ Variables } & \multirow[b]{2}{*}{ Categories } & \multirow[b]{2}{*}{$\mathbf{n}$} & \multirow[b]{2}{*}{$\%$} & \multicolumn{2}{|c|}{ FFA } & \multicolumn{2}{|c|}{ FFB } & \multicolumn{2}{|c|}{ FFC } \\
\hline & & & & Mean & SD & Mean & SD & Mean & SD \\
\hline \multirow{2}{*}{$\begin{array}{l}\text { Age (yrs) } \\
\text { Mean: } 39.1 \\
\text { SD: } 9.8\end{array}$} & & 1,048 & 100.0 & 22.5 & 5.9 & 22.3 & 6.1 & 16.4 & 4.9 \\
\hline & & & & & p-value & & p-value & & p-value \\
\hline Age & $21-39$ years & 586 & 55.9 & 23.1 & 0.000 & 22.5 & 0.150 & 16.9 & 0.000 \\
\hline Group & $40-67$ years & 462 & 44.1 & 21.6 & & 21.9 & & 15.8 & \\
\hline \multirow[t]{2}{*}{ Sex } & Female & 32 & 3.0 & 22.0 & 0.560 & 21.5 & 0.465 & 17.4 & 0.303 \\
\hline & Male & 1,016 & 97.0 & 22.5 & & 22.3 & & 16.4 & \\
\hline Job & Captain & 602 & 57.4 & 22.4 & 0.092 & 22.5 & 0.010 & 16.3 & 0.250 \\
\hline Position & Co-pilot & 446 & 42.6 & 22.6 & & 21.9 & & 16.5 & \\
\hline
\end{tabular}

Note. $(*)$ SD: standard deviation; p-value: significance level $<0.05$ (bold). 
While modification indices should be avoided in general, they can be useful for representing known effects, such as the correlation between the errors in the measurement process or data collection (Hair et al., 2009), a frequent phenomenon in psychometric measures such as the Feeling of Fatigue scale. Thus, 40 correlations were added to the measurement model, based on modification indices above an improvement cut-off of $20(0.5 \%)$ on the chi-square statistics exhibiting significance $(\mathrm{p}<0.05)$ (Table 4).

Table 4

\section{Modification indices included}

\begin{tabular}{lllll}
\hline FFA01 FFA06 & FFA03 FFA05 & FFA05 FFA08 & FFB11 FFB14 & FFB16 FFB17 \\
FFA02 FFA03 & FFA03 FFA06 & FFA06 FFA07 & FFB11 FFB18 & FFB19 FFB20 \\
FFA02 FFA04 & FFA03 FFA07 & FFA06 FFA08 & FFB12 FFB13 & FFC21 FFC22 \\
FFA02 FFA06 & FFA03 FFA08 & FFA06 FFA09 & FFB14 FFB15 & FFC23 FFC27 \\
FFA02 FFA07 & FFA04 FFA05 & FFA07 FFA08 & FFB14 FFB18 & FFC24 FFC27 \\
FFA02 FFA08 & FFA04 FFA06 & FFA08 FFA09 & FFB14 FFB19 & FFC24 FFC28 \\
FFA02 FFA10 & FFA04 FFA07 & FFA08 FFA10 & FFB14 FFB20 & FFC25 FFC26 \\
FFA03 FFA04 & FFA04 FFA08 & FFB11 FFB13 & FFB15 FFB18 & FFC28 FFC29 \\
\hline
\end{tabular}

Note. $\left({ }^{*}\right) \sim \sim$ in lavaan, denotes correlation between error terms of indicators measured.

Table 5 compares fit measures and reliability before and after inclusion of modification indices. Adequate fit measures and reliability were obtained for the measurement model. Although the chi-square statistics remained non-significant, the other quality indices (CFI, RMSEA, SRMR) presented satisfactory results. The model incorporating modification indices had the best parsimony (AIC). In addition, the coefficient alpha values confirmed the reliability and internal consistency of the instrument. Therefore, these results confirm the convergent validation of the internal structure.

Table 5

Fit measures and reliability

\begin{tabular}{|c|c|c|c|c|c|c|}
\hline & \multicolumn{3}{|c|}{ Without modification indices } & \multicolumn{3}{|c|}{ With modification indices } \\
\hline & Value & $\begin{array}{l}\text { Degrees of } \\
\text { freedom }\end{array}$ & $p$-value & Value & $\begin{array}{l}\text { Degrees of } \\
\text { freedom }\end{array}$ & $p$-value \\
\hline Chi-square & 4,052 & 402 & 0.000 & 1,018 & 362 & 0.000 \\
\hline $\mathrm{CFI}$ & 0.735 & & & 0.952 & & \\
\hline AIC & 69,060 & & & 66,106 & & \\
\hline RMSEA & 0.093 & & & 0.042 & & \\
\hline SRMR & 0.080 & & & 0.036 & & \\
\hline \multicolumn{7}{|c|}{ Reliability coefficient: alpha } \\
\hline - FFA & 0.814 & & & 0.814 & & \\
\hline - FFB & 0.859 & & & 0.859 & & \\
\hline - FFC & 0.823 & & & 0.823 & & \\
\hline
\end{tabular}

Finally, cross-validation between groups with the final measurement model was performed only for groups with significant differences on mean comparisons (Table 3). The following models

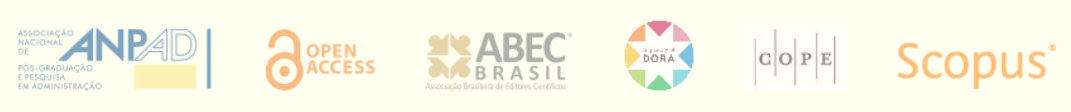


were evaluated: Model 1 - all available data; Model 2 - age group comparison; Model 3 - job group comparisons. First, a loose cross-validation (Hair et al., 2009) was applied in order to check measurement invariance of latent variable correlations, loadings, and error variances. Table 6 shows similar correlations between latent variables for Models 1, 2, and 3. Tables 7, 8, and 9 show comparisons of loadings and error variances (uniqueness) for latent variables (FFA, FFB, and FFC), respectively. In Table 7, similar loadings result in similar average variance extracted (AVE), representing the sum of communalities divided by 10. Error variances (uniqueness) were also similar. In Table 8, similar loadings and error variances were also obtained. As results proved similar in Table 9, a loose cross-validation was shown.

Table 6

Group comparisons - latent variable correlations

\begin{tabular}{lccccccccc}
\hline & \multicolumn{3}{c}{ Model 1 } & \multicolumn{3}{c}{ Model 2 - Age } & \multicolumn{3}{c}{ Model 3 - Job } \\
\cline { 2 - 10 } $\begin{array}{l}\text { Latent } \\
\text { constructs }\end{array}$ & FFA & FFB & FFC & FFA & FFB & FFC & FFA & FFB & FFC \\
FFA & $\mathbf{0 . 5 9 5}$ & & & $\mathbf{0 . 6 0 1}$ & & & $\mathbf{0 . 5 9 7}$ & \\
FFB & 0.840 & $\mathbf{0 . 6 3 2}$ & & 0.868 & $\mathbf{0 . 6 4 8}$ & & 0.811 & $\mathbf{0 . 6 1 5}$ & \\
FFC & 0.834 & 0.746 & $\mathbf{0 . 5 6 7}$ & 0.820 & 0.752 & $\mathbf{0 . 5 8 6}$ & 0.813 & 0.716 & $\mathbf{0 . 5 8 0}$ \\
\hline
\end{tabular}

Table 7

FFA - group cross-validation — age group - standardized values

\begin{tabular}{ccccccccc}
\hline & \multicolumn{1}{c}{ Group } & \multicolumn{4}{c}{ Age: 21-39 years } & \multicolumn{3}{c}{ Age: 40-67 years } \\
\hline Indicator & Loading & p-value & Comm. & Uniq. & Loading & p-value & Comm. & Uniq. \\
\hline FFA01 & 0.608 & 0.000 & 0.370 & 0.630 & 0.622 & 0.000 & 0.387 & 0.613 \\
FFA02 & 0.592 & 0.000 & 0.351 & 0.649 & 0.613 & 0.000 & 0.376 & 0.624 \\
FFA03 & 0.392 & 0.000 & 0.154 & 0.846 & 0.476 & 0.000 & 0.226 & 0.774 \\
FFA04 & 0.633 & 0.000 & 0.401 & 0.599 & 0.646 & 0.000 & 0.417 & 0.583 \\
FFA05 & 0.724 & 0.000 & 0.524 & 0.476 & 0.645 & 0.000 & 0.416 & 0.584 \\
FFA06 & 0.726 & 0.000 & 0.527 & 0.473 & 0.754 & 0.000 & 0.569 & 0.431 \\
FFA07 & 0.657 & 0.000 & 0.431 & 0.569 & 0.678 & 0.000 & 0.460 & 0.540 \\
FFA08 & 0.140 & 0.002 & 0.020 & 0.980 & 0.274 & 0.000 & 0.075 & 0.925 \\
FFA09 & 0.534 & 0.000 & 0.285 & 0.715 & 0.476 & 0.000 & 0.226 & 0.774 \\
FFA10 & 0.612 & 0.000 & 0.374 & 0.626 & 0.679 & 0.000 & 0.462 & 0.538 \\
& FFA & Sum & 3.437 & 6.563 & FFA & Sum & 3.614 & 6.386 \\
\hline
\end{tabular}

Note. $\left({ }^{\star}\right)$ Comm. $=$ Communality; Uniq. $=$ Uniqueness. 
Table 8

FFB - group cross-validation - job position - standardized values

\begin{tabular}{crrrrrrrr}
\hline Group & \multicolumn{4}{c}{ Job: Captain } \\
\hline Indicator & Loading & p-value & \multicolumn{1}{c}{ Comm. } & Uniq. & Loading & p-value & Comm. & Uniq. \\
\hline FFB11 & 0.744 & 0.000 & 0.554 & 0.446 & 0.723 & 0.000 & 0.522 & 0.478 \\
FFB12 & 0.631 & 0.000 & 0.398 & 0.602 & 0.641 & 0.000 & 0.411 & 0.589 \\
FFB13 & 0.611 & 0.000 & 0.373 & 0.627 & 0.579 & 0.000 & 0.335 & 0.665 \\
FFB14 & 0.812 & 0.000 & 0.659 & 0.341 & 0.786 & 0.000 & 0.617 & 0.383 \\
FFB15 & 0.565 & 0.000 & 0.320 & 0.680 & 0.569 & 0.000 & 0.323 & 0.677 \\
FFB16 & 0.739 & 0.000 & 0.547 & 0.453 & 0.689 & 0.000 & 0.475 & 0.525 \\
FFB17 & 0.597 & 0.000 & 0.356 & 0.644 & 0.586 & 0.000 & 0.343 & 0.657 \\
FFB18 & 0.511 & 0.000 & 0.262 & 0.738 & 0.447 & 0.000 & 0.200 & 0.800 \\
FFB19 & 0.607 & 0.000 & 0.369 & 0.631 & 0.551 & 0.000 & 0.304 & 0.696 \\
FFB20 & 0.551 & 0.000 & 0.304 & 0.696 & 0.500 & 0.000 & 0.250 & 0.750 \\
& FFB & Sum & 4.142 & 5.858 & FFB & Sum & 3.780 & 6.220 \\
\hline
\end{tabular}

Note. $\left({ }^{*}\right)$ Comm. $=$ Communality; Uniq. = Uniqueness.

Table 9

FFC - group cross-validation - age group - standardized values

\begin{tabular}{crrrrrrrr}
\hline Group & \multicolumn{4}{c}{ Age: 21-39 years } & \multicolumn{5}{c}{ Age: 40-67 years } \\
\hline Indicator & Loading & p-value & Comm. & Uniq. & Loading & p-value & Comm. & Uniq. \\
\hline FFC21 & 0.537 & 0.000 & 0.288 & 0.712 & 0.548 & 0.000 & 0.300 & 0.700 \\
FFC22 & 0.708 & 0.000 & 0.501 & 0.499 & 0.680 & 0.000 & 0.462 & 0.538 \\
FFC23 & 0.578 & 0.000 & 0.334 & 0.666 & 0.669 & 0.000 & 0.448 & 0.552 \\
FFC24 & 0.503 & 0.000 & 0.253 & 0.747 & 0.582 & 0.000 & 0.338 & 0.662 \\
FFC25 & 0.507 & 0.000 & 0.258 & 0.742 & 0.596 & 0.000 & 0.355 & 0.645 \\
FFC26 & 0.520 & 0.000 & 0.271 & 0.729 & 0.557 & 0.000 & 0.310 & 0.690 \\
FFC27 & 0.487 & 0.000 & 0.237 & 0.763 & 0.567 & 0.000 & 0.322 & 0.678 \\
FFC28 & 0.548 & 0.000 & 0.300 & 0.700 & 0.559 & 0.000 & 0.313 & 0.687 \\
FFC29 & 0.496 & 0.000 & 0.246 & 0.754 & 0.546 & 0.000 & 0.298 & 0.702 \\
FFC30 & 0.597 & 0.000 & 0.356 & 0.644 & 0.542 & 0.000 & 0.293 & 0.707 \\
& FFC & Sum & 3.044 & 6.956 & FFC & Sum & 3.439 & 6.561 \\
\hline
\end{tabular}

Note. $\left(^{*}\right)$ Comm. $=$ Communality; Uniq. $=$ Uniqueness. 
Table 10

Group cross-validation — loadings equivalence

\begin{tabular}{lccccccl}
\hline Model & $\begin{array}{c}\text { Degrees } \\
\text { of } \\
\text { freedom }\end{array}$ & $\begin{array}{c}\text { Chi- } \\
\text { square }\end{array}$ & $\begin{array}{c}\text { Chi-sq. } \\
\text { Diff. }\end{array}$ & p-value & CFI & RMSEA & Comments \\
\hline $2-$ age $\left(^{*}\right)$ & 724 & $1,440.41$ & & & 0.948 & 0.043 & Good fit \\
$2-$ age $\left(^{* *}\right)$ & 751 & $1,480.16$ & 39.75 & 0.0540 & 0.947 & 0.043 & Non-significant difference \\
$3-$ job $\left(^{*}\right)$ & 724 & $1,460.17$ & & & 0.947 & 0.044 & Good fit \\
$3-$ job $\left(^{* *}\right)$ & 751 & $1,487.27$ & 27.10 & 0.4583 & 0.947 & 0.043 & Non-significant difference \\
\hline
\end{tabular}

Note. $\left(^{\star}\right)$ loose cross-validation models; $\left({ }^{* *}\right)$ loadings equivalence models.

For loadings equivalence cross-loading, Models 2 and 3 were compared, with free estimation and non-standardized loadings set to be equal in the respective models. The results in Table 10 also confirm cross-validation by this alternative procedure. Therefore, convergent validity was confirmed for the first-order trifactorial tau-equivalent measurement model of the Feeling of Fatigue scale.

\section{Discriminant validity of constructs}

The final stage involved the assessment of discriminant validity among the three constructs (FFA, FFB, and FFC). Composite reliability (CR) derived from coefficient alpha. Average variance extracted (AVE) and correlations among the three constructs were measured to evaluate FornellLarcker criterion (Fornell \& Larcker, 1981) and compare Heterotrait-Monotrait (HTMT) criterion (Voorhees et al., 2016) against the cut-off of 0.85 (Table 11).

Table 11

\section{Discriminant validity}

\begin{tabular}{|c|c|c|c|c|c|c|c|c|}
\hline \multirow[b]{2}{*}{$\begin{array}{l}\text { Latent } \\
\text { constructs }\end{array}$} & \multirow[b]{2}{*}{$\begin{array}{c}\text { CR } \\
\text { alpha }\end{array}$} & \multirow[b]{2}{*}{ AVE } & \multirow[b]{2}{*}{ FFA } & \multirow[b]{2}{*}{ FFB } & \multicolumn{2}{|c|}{$\begin{array}{l}\text { Fornell-Larcker } \\
\text { (Correlations) }\end{array}$} & \multicolumn{2}{|c|}{ НTMT } \\
\hline & & & & & FFC & FFA & FFB & FFC \\
\hline FFA & 0.8140 & 0.3538 & 0.595 & & & - & & \\
\hline FFB & 0.8587 & 0.3991 & 0.840 & 0.632 & & 1.005 & - & \\
\hline FFC & 0.8235 & 0.3209 & 0.834 & 0.746 & 0.567 & 1.019 & 0.887 & - \\
\hline
\end{tabular}

For discriminant validity according to Fornell-Larcker criterion, the square root of AVE in the diagonal of the correlation matrix must be larger than the off-diagonal terms. Alternatively, using the HTMT criterion, calculated ratios between correlation and the square root of reliability term products must be less than 0.85 . The results failed for both criteria. Although it was ensured that indicators were related to a single latent variable and there were no cross-loadings, discriminant validity was rejected. This outcome confirms that the three constructs are interrelated for measuring feeling of fatigue (Yoshitake, 1971).

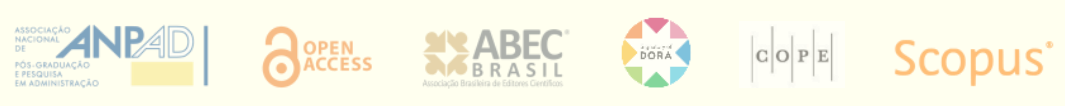




\section{DISCUSSION}

The measurement of feeling of fatigue at work is particularly important in the case of shift workers, such as civil aviation pilots, the target population of the present study. As outlined earlier, fatigue is a major issue affecting the occupational health and safety of pilots, exacerbated by a number of factors inherent to the profession. In this study, a convergent-discriminant validation analysis of a Portuguese version of the Feeling of Fatigue scale was performed in the organizational context of civil aviation. As recommended in the literature (Hutz et al., 2015), construct validity of the Feeling of Fatigue scale was evaluated by confirmatory factor analysis and analysis of internal consistency, with the latter approach based on reliability measures.

Different procedures were applied to confirm convergent validity, including group comparisons for cross-validation. No comparison was performed for sex, because no significant gender differences in fatigue scores were found for the three latent variables. Discriminant validity was rejected by two alternative methods, confirming that the three latent variables indeed measure different interrelated aspects of fatigue (Yoshitake, 1971). The various fit quality indicators in the structural equations model (Hair et al., 2009) were compared. Reliability measured by coefficient alpha for tau-equivalent models was included as part of the overall convergent-discriminant validation analysis carried out. The results provided confirmation of psychometric validity of the first-order trifactorial tau-equivalent measurement model of the Feeling of Fatigue scale.

Confirmatory factor analysis is often used to assess scale reliability and construct validity through convergent and discriminant analyses in Administration research studies (Demo, Neiva, Nunes, \& Rozzett, 2012; Santos \& Brito, 2012). Sometimes, exploratory factor analyses are also applied (Neiva, Odelius, \& Ramos, 2015; Wimalasiri, 1995), but only sample adequacy was proved in the present study, given the scale was originally validated with the same first-order trifactorial model. Previous studies have shown that content validity of a scale, in a cultural adaptation to another language, can be inferred from the analysis of the internal structure and reliability of the instrument (Boada-Grau, Merino-Tejedor, Gil-Ripoll, Segarra-Perez, \& Vigil-Colet, 2014; Gouveia et al., 2015; Hutz et al., 2015). Validation of a scale based on the measure of its reliability is a widely used technique (Hutz et al., 2015).

Although this study validated the first-order trifactorial model originally proposed, it is believed that a one-dimensional instrument could evaluate fatigue at work. In a previous study (De Vries, Michielsen, \& Van Heck, 2003), failure to confirm multidimensionality might have been due to the fact that fatigue manifests itself as a one-dimensional construct for healthy individuals. However, fatigue can manifest multidimensionality owing to symptoms reported by patients. Results of the Feeling of Fatigue scale are usually expressed as an aggregate score. However, it is also accepted that fatigue should not be reduced to a single dimension, because it encompasses multidimensional, dynamically interdependent, yet not fully correlated aspects. These aspects provide a description of how fatigue reflects psychophysiological states and performance, and should be considered from a systemic perspective (Phillips, 2015). Consequently, the analysis of multiple constructs in the Feeling of Fatigue scale proves important.

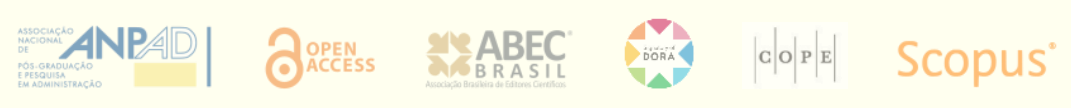


The absence of robust results on fatigue measurements precludes the ranking of measuring instruments by effectiveness (Phillips, Kecklund, Anund, \& Sallinen, 2017). A lack of consistency in the use of these instruments hampers comparison and validation of different fatigue measurements. There is also no golden rule for establishing the existence of fatigue and the validity of instruments measuring fatigue cannot be proven (Beurskens et al., 2000). In the absence of this consensus, convergent-discriminant validation is applied. The results of the present analysis of convergent-discriminant validation serve to confirm the validity of the Feeling of Fatigue scale. Therefore, the present study helps further knowledge on the measurement of fatigue.

\section{FINAL COMMENTS AND FURTHER RESEARCH}

Discussions on fatigue risk management systems (FRMS) recommend that validated instruments measuring fatigue be applied to capture different related constructs. FRMS are a fast-growing regulatory trend set to further research on occupational stress in Administration.

This study fills a gap in the occupational stress literature in Administration by highlighting the relevance of research on fatigue at work and validating the Portuguese version of the Feeling of Fatigue scale in Brazil. The instrument is important for fatigue management in the workplace. The scarcity of similar studies in Administration journals should be addressed, given the relevance of the subject in the international scientific literature.

Follow-up studies involving further analysis and collection of new data samples are underway. These investigations may help determine a more accurate prevalence of fatigue based on the Feeling of Fatigue scale in the organizational context, and support validation of other scales measuring fatigue and related constructs. The authors believe this research in the Administration area will likely increase, as more and more organizations from different sectors strive to implement and operationalize fatigue management systems.

\section{ACKNOWLEDGMENTS}

The authors acknowledge the support of the Brazilian Association of Civil Aviation Pilots (Abrapac), associated with the IFALPA (International Federation of Airline Pilots' Associations), for providing the research database on Brazilian pilots' chronic fatigue, work conditions, and health.

\section{REFERENCES}

Aghdam, S. R., Alizadeh, S. S., Rasoulzadeh, Y., \& Safaiyan, A. (2019). Fatigue assessment scales: A comprehensive literature review. Archives of Hygiene Sciences, 8(3), 145-153. https://doi.org/10.29252/archhygsci.8.3.145

Almirall, P., \& Reyes, M. (1982). Relación entre índices subjetivos y objetivos de fatiga. Validación de una prueba. Revista Cubana de Higiene y Epidemiología, 20, 239-248.
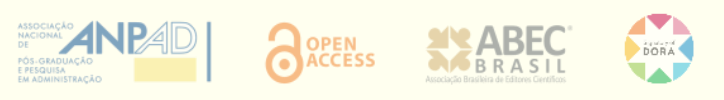
Barrientos-Gutierrez, T., Martinez-Alcantara, S., \& Mendez-Ramirez, I. (2004). Validez de constructo, confiabilidad y punto de corte de la prueba de síntomas subjetivos de fatiga en trabajadores mexicanos. Salud Publica De Mexico, 46(6), 516-523. https://doi.org/10.1590/s0036-36342004000600006

Bendak, S., \& Rashid, H. S. J. (2020). Fatigue in aviation: A systematic review of the literature. International Journal of Industrial Ergonomics, 76, 102928. https://doi.org/10.1016/j.ergon.2020.102928

Beurskens, A., Bultmann, U., Kant, I., Vercoulen, J., Bleijenberg, G., \& Swaen, G. M. H. (2000). Fatigue among working people: Validity of a questionnaire measure. Occupational and Environmental Medicine, 57(5), 353-357. https://doi.org/10.1136/oem.57.5.353

Bido, D. S. (2019). Modelagem de equações estruturais: Uma visão aplicada para a engenharia. In P. A. CauchikMiguel (Ed.), Metodologia científica para engenharia (pp. 81-108). Rio de Janeiro: Elsevier Brasil.

Bliese, P. D., Edwards, J. R., \& Sonnentag, S. (2017). Stress and well-being at work: A century of empirical trends reflecting theoretical and societal influences. Journal of Applied Psychology, 102(3), 389-402. https://doi.org/10.1037/ap10000109

Boada-Grau, J., Merino-Tejedor, E., Gil-Ripoll, C., Segarra-Perez, G., \& Vigil-Colet, A. (2014). Adaptación al español del inventario multidimensional de fatiga al entorno laboral. Universitas Psychologica, 13(4), 1279-1287. Retrieved from https://psycnet.apa.org/record/2016-43640-005

Breakwell, G. M., Smith, J. A., \& Wright, D. B. (2012). Research methods in psychology (4th ed.). London: Sage Publications.

Caldwell, J. A., Mallis, M. M., Caldwell, J. L., Paul, M. A., Miller, J. C., \& Neri, D. F. (2009). Fatigue countermeasures in aviation. Aviation, Space, and Environmental Medicine, 80(1), 29-59. https://doi.org/10.3357/asem.2435.2009

Campbell, D. T., \& Fiske, D. W. (1959). Convergent and discriminant validation by the multitrait-multimethod matrix. Psychological Bulletin, 56(2), 81-105. https://doi.org/10.1037/h0046016

Cauchik-Miguel, P. A., Fleury, A., Mello, C. H. P., Nakano, D. N., Lima, E. P., Turrioni, J. B., Ho, L. L., Morabito, R., Martins, R., Sousa, R., Costa, S., \& Pureza, V. (2018). Metodologia de pesquisa em engenharia de produção e gestão de operações. Rio de Janeiro: Elsevier Brasil.

Chang, F.-L., Sun, Y.-M., Chuang, K.-H., \& Hsu, D.-J. (2009). Work fatigue and physiological symptoms in different occupations of high-elevation construction workers. Applied Ergonomics, 40(4), 591-596. https://doi.org/10.1016/j.apergo.2008.04.017

Cousineau, D., \& Chartier, S. (2010). Outliers detection and treatment: A review. International Journal of Psychological Research, 3(1), 58-67. https://doi.org/10.21500/20112084.844

Creswell, J. W. (2014). Research design: Qualitative, quantitative and mixed methods approaches (4th ed.). Thousand Oaks: Sage Publications.

Darwent, D., Dawson, D., Paterson, J. L., Roach, G. D., \& Ferguson, S. A. (2015). Managing fatigue: It really is about sleep. Accident Analysis and Prevention, 82, 20-26. https://doi.org/10.1016/j.aap.2015.05.009

De Vries, J., Michielsen, H. J., \& Van Heck, G. L. (2003). Assessment of fatigue among working people: A comparison of six questionnaires. Occupational and Environmental Medicine, 60(suppl 1), i10-i15. https://doi.org/10.1136/oem.60.suppl_1.i10

Demo, G., Neiva, E. R., Nunes, I., \& Rozzett, K. (2012). Human resources management policies and practices scale (HRMPPS): Exploratory and confirmatory factor analysis. BAR - Brazilian Administration Review, 9(4), 395-420. https://doi.org/10.1590/s1807-76922012005000006

Drongelen, A. van, Boot, C. R. L., Hlobil, H., Beek, A. J. van der, \& Smid, T. (2017). Cumulative exposure to shift work and sickness absence: Associations in a five-year historic cohort. BMC Public Health, 17(1), 67. https://doi.org/10.1186/s12889-016-3906-z

Ferreira, C. A. A., Reis, M. T., Neto, Kilimnik, Z. M., \& Santos, A. S. dos. (2016). O contexto do estresse ocupacional dos trabalhadores da saúde: Estudo bibliométrico. Revista de Gestão em Sistemas de Saúde, 5(2), 84-99. https://doi.org/10.5585/rgss.v5i2.233

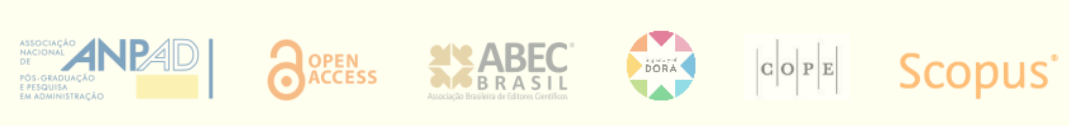


Fischer, F. M. (1990). Condições de vida e de trabalho de trabalhadores da indústria petroquímica (Dissertation thesis). Universidade de São Paulo, São Paulo, Brazil. Retrieved from https://pesquisa.bvsalud.org/portal/resource/pt/lil-92642?lang=en

Fontelles, M. J., Simões, M. G., Farias, S. H., \& Fontelles, R. G. S. (2009). Metodologia da pesquisa científica: Diretrizes para a elaboração de um protocolo de pesquisa. Revista Paraense de Medicina, 23(3), 1-8.

Fornell, C., \& Larcker, D. F. (1981). Evaluating structural equation models with unobservable variables and measurement error. Journal of Marketing Research, 18(1), 39-50. https://doi.org/10.2307/3151312

Gaillard, A. W. (2001). Stress, workload and fatigue as three biobehavioral states: A general overview. In P. A. Hancock \& P. A. Desmond (Eds.), Stress, workload and fatigue (pp. 623-639). Boca Raton, FL: CRC Press.

Gana, K., \& Broc, G. (2018). Structural equation modeling with lavaan. London: Wiley-ISTE

Gander, P. H. (2015). Evolving regulatory approaches for managing fatigue risk in transport operations. Reviews of Human Factors and Ergonomics, 10(1), 253-271. https://doi.org/10.1177/1557234X15576510

Gander, P., Hartley, L., Powell, D., Cabon, P., Hitchcock, E., Mills, A., \& Popkin, S. (2011). Fatigue risk management: Organizational factors at the regulatory and industry/company level. Accident Analysis Eु Prevention, 43(2), 573-590. https://doi.org/10.1016/j.aap.2009.11.007

Gander, P., Mangie, J., Berg, M. J. van den, Smith, A. A. T., Mulrine, H. M., \& Signal, T. L. (2014). Crew fatigue safety performance indicators for fatigue risk management systems. Aviation, Space, and Environmental Medicine, 85(2), 139-147. https://doi.org/10.3357/ASEM.3748.2014

Gander, P., Mangie, J., Phillips, A., Santos-Fernandez, E., \& Wu, L. J. (2018). Monitoring the effectiveness of fatigue risk management: A survey of pilots' concerns. Aerospace Medicine and Human Performance, 89(10), 889-895. https://doi.org/10.3357/AMHP.5136.2018

Gawron, V. J. (2016). Overview of self-reported measures of fatigue. The International Journal of Aviation Psychology, 26(3-4), 120-131. https://doi.org/10.1080/10508414.2017.1329627

Glendon, A. I., Clarke, S. G., \& Mckenna, E. F. (2006). Human safety and risk management (2nd ed.). Boca Raton, FL: CRC Press.

Gouveia, V. V, Oliveira, G. F. de, Mendes, L. A. de C., Souza, L. E. C. de, Cavalcanti, T. M., \& Melo, R. L. P. de. (2015). Escala de avaliação da fadiga: Adaptação para profissionais da saúde. Revista Psicologia Organizações e Trabalho, 15(3), 246-256. https://doi.org/10.17652/rpot/2015.3.594

Graham, J. M. (2006). Congeneric and (essentially) tau-equivalent estimates of score reliability: What they are and how to use them. Educational and Psychological Measurement, 66(6), 930-944. https://doi.org/10.1177/0013164406288165

Hair, J. F., Jr., Black, W., Babin, B. J, \& Anderson, R. E. (2009). Análise multivariada de dados (6th ed.). Porto Alegre: Bookman

Hancock, P. A., \& Desmond, P. A. (2001). Stress, worload, and fatigue. Boca Raton: CRC Press.

Henseler, J., Ringle, C. M., \& Sarstedt, M. (2015). A new criterion for assessing discriminant validity in variancebased structural equation modeling. Journal of the Academy of Marketing Science, 43(1), 115-135. https://doi.org/10.1007/s11747-014-0403-8

Hockey, R. (2013). The psychology of fatigue: Work, effort and control. Cambridge: Cambridge University Press.

Hofmann, D. A., Burke, M. J., \& Zohar, D. (2017). 100 years of occupational safety research: From basic protections and work analysis to a multilevel view of workplace safety and risk. Journal of Applied Psychology, 102(3), 375-388. https://doi.org/10.1037/ap10000114

Hooper, D., Coughlan, J., \& Mullen, M. (2008). Evaluating model fit: A synthesis of the structural equation modelling literature. European Conference on Research Methodology for Business and Management Studies, London, United Kingdom, 7. https://doi.org/10.21427/D79B73

Hutz, C. S., Bandeira, D. R., \& Trentini, C. M. (2015). Psicometria. Porto Alegre: Artmed.

ISO. (2017). ISO 10075-1:2017 Ergonomic principles related to mental workload - part 1: General issues and concepts, terms and definitions. Retrieved from https://www.iso.org/standard/66900.html

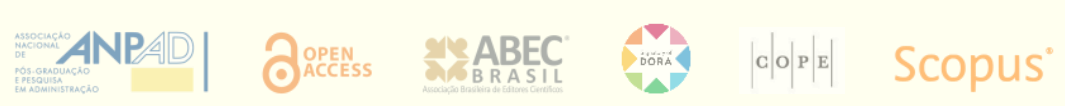


Lerman, S. E., Eskin, E., Flower, D. J., George, E. C., Gerson, B., Hartenbaum, N., Hursh, S. R., \& Moore-Ede, M. (2012). Fatigue risk management in the workplace. Journal of Occupational and Environmental Medicine, 54(2), 231258. https://doi.org/10.1097/jom.0b013e318247a3b0

Mallis, M. M., Banks, S., \& Dinges, D. F. (2010). Aircrew fatigue, sleep need and circadian rhythmicity. In E. Salas \& D. Maurino (Eds.), Human factors in aviation (2 ed., pp. 401-436). Burlington: Elsevier.

Mallis, M. M., \& James, F. O. (2012). The role of alertness monitoring in sustaining cognition during sleep loss. In N. J. Wesensten (Ed.), Sleep deprivation, stimulant, medications, and cognition (pp. 209-222). Cambridge: Cambridge University Press.

Marqueze, E. C., Diniz, D. H. M. D., \& Nicola, A. C. B. (2014). Fadiga crônica, condições de trabalho e saúde em pilotos brasileiros [Working Paper]. Associação Brasileira de Pilotos da Aviação Civil - ABRAPAC, São Paulo, SP, Brazil.

Marqueze, E. C., Nicola, A. C. B., Diniz, D. H. M. D., \& Fischer, F. M. (2017). Working hours associated with unintentional sleep at work among airline pilots. Revista de Saúde Pública, 51, 61. https://doi.org/10.1590/S1518-8787.2017051006329

Matheson, A., O’Brien, L., \& Reid, J.-A. (2014). The impact of shiftwork on health: A literature review. Journal of Clinical Nursing, 23(23-24), 3309-3320. https://doi.org/10.1111/jocn.12524

Matthews, G., Desmond, P. A., Neubauer, C., \& Hancock, P. A. (2018). An overview of operator fatigue. In The Handbook of Operator Fatigue (pp. 3-23). Boca Raton, FL: CRC Press.

Mélan, C., \& Cascino, N. (2014). A multidisciplinary approach of workload assessment in real-job situations: Investigation in the field of aerospace activities. Frontiers in Psychology, 5, 964. https://doi.org/10.3389/fpsyg.2014.00964

Metzner, R. J., \& Fischer, F. M. (2001). Fadiga e capacidade para o trabalho em turnos fixos de doze horas. Rev Saúde Pública, 35(6), 548-553. http://dx.doi.org/10.1590/S0034-89102001000600008.

Metzner, R. J., Fischer, F. M., \& Nogueira, D. P. (2008). Comparação da percepção de fadiga e de capacidade para o trabalho entre trabalhadores têxteis de empresas que se encontram em diferentes estágios de responsabilidade social empresarial no estado de São Paulo, Brasil. Saúde e Sociedade, 17(4), 46-55. https://doi.org/10.1590/S0104-12902008000400006

Monteiro, R., Pereira, M., Daniel, F., Silva, A. G. da, \& Matos, F. R. N. (2017). The influence of organizational reconciliation policies and culture on workers stress perceptions. BAR - Brazilian Administration Review, 14(3), e170005. https://doi.org/10.1590/1807-7692bar2017170005

Morris, M. B., Wiedbusch, M. D., \& Gunzelmann, G. (2018). Fatigue incident antecedents, consequences, and aviation operational risk management resources. Aerospace Medicine and Human Performance, 89(8), 708-716. https://doi.org/10.3357/AMHP.5019.2018

Neiva, E. R., Odelius, C. C., \& Ramos, L. D. (2015). The organizational change process: Its influence on competences learned on the job. BAR - Brazilian Administration Review, 12(4), 324-347. https://doi.org/10.1590/1807-7692bar2015140082

Norman, G. (2010). Likert scales, levels of measurement and the "laws" of statistics. Advances in Health Sciences Education, 15(5), 625-632. https://doi.org/10.1007/s10459-010-9222-y

Nunes, A., \& Cabon, P. (2015). The fatigue conundrum. American Scientist, 103(3), 218-223. https://doi.org/10.1511/2015.114.218

Parody, A., Viloria, A., Hernandez, M., Niño, A., \& Cervera, J. (2020). Integration of statistical techniques to evaluate the fatigue of operators on the productivity of a company. In Advances in Intelligent Systems and Computing (Vol. 1039, pp. 53-62). https://doi.org/10.1007/978-3-030-30465-2_7

Paschoal, T., \& Tamayo, Á. (2004). Validação da escala de estresse no trabalho. Estudos de Psicologia, 9(1), 45-52. http://dx.doi.org/10.1590/S1413-294X2004000100006.

Pasquali, L. (2007). Validade dos testes psicológicos: Será possível reencontrar o caminho? Psicologia: Teoria e Pesquisa, 23(spe), 99-107. https://doi.org/10.1590/S0102-37722007000500019

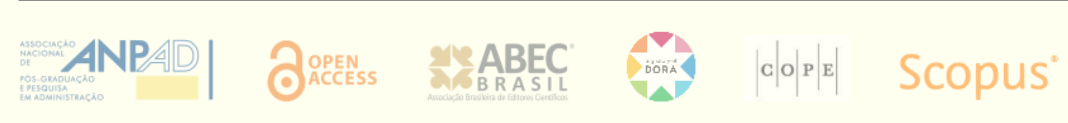


Phillips, R. O. (2015). A review of definitions of fatigue: And a step towards a whole definition. Transportation Research Part F: Traffic Psychology and Behaviour, 29, 48-56. https://doi.org/10.1016/j.trf.2015.01.003

Phillips, R. O., Kecklund, G., Anund, A., \& Sallinen, M. (2017). Fatigue in transport: A review of exposure, risks, checks and controls. Transport Reviews, 37(6), 742-766. https://doi.org/10.1080/01441647.2017.1349844

R Core Team. (2019). R: A language and environment for statistical computing. Vienna, Austria: R Foundation for Statistical Computing.

R Studio Team. (2019). RStudio: Integrated development for R. Boston/MA: RStudio, Inc.

Raykov, T. (1997a). Estimation of composite reliability for congeneric measures. Applied Psychological Measurement, 21(2), 173-184. https://doi.org/10.1177\%2F01466216970212006

Raykov, T. (1997b). Scale reliability, cronbach's coefficient alpha, and violations of essential tau-equivalence with fixed congeneric components. Multivariate Behavioral Research, 32(4), 329-353. https://doi.org/10.1207/s15327906mbr3204_2

Rios, J., \& Wells, C. (2014). Validity evidence based on internal structure. Psicothema, 26(1), 108-116. https://doi.org/10.7334/psicothema2013.260

Rosseel, Y. (2012). Lavaan : An R package for structural equation modeling. Journal of Statistical Software, 48(2), 136. https://doi.org/10.18637/jss.v048.i02

Sagherian, K., \& Brown, J. G. (2016). In-depth review of five fatigue measures in shift workers. Fatigue: Biomedicine Health and Behavior, 4(1), 24-38. https://doi.org/10.1080/21641846.2015.1124521

Saito, Y. (1982). The validity of japanese fatigue feeling scale [abstract]. Ergonomics, 25(6), 473.

Santos, J. B., \& Brito, L. A. L. (2012). Toward a subjective measurement model for firm performance. BAR - Brazilian Administration Review, 9(spe), 95-117. https://doi.org/10.1590/S1807-76922012000500007

Sasangohar, F., Jones, S. L., Masud, F. N., Vahidy, F. S., \& Kash, B. A. (2020). Provider burnout and fatigue during the Covid-19 pandemic: Lessons learned from a high-volume intensive care unit. Anesthesia and Analgesia, 131(1), 106-111. https://doi.org/10.1213/ANE.0000000000004866

Silva, A. C. da, Queija, C. C. S., Ferreira, S. G., Vargas, L. S., Benício, P. R., \& Bueno, A. D. A. (2015). Contemporary perception of pleasure and suffering in the organizational environment. Revista de Enfermagem UFPE on Line, 9(8), 8908-8915. https://doi.org/10.5205/1981-8963-v9i8a10677p8908-8915-2015

Smith, B. P., Browne, M., Armstrong, T. A., \& Ferguson, S. A. (2016). The accuracy of subjective measures for assessing fatigue related decrements in multi-stressor environments. Safety Science, 86, 238-244. https://doi.org/10.1016/j.ssci.2016.03.006

Sonnentag, S., \& Frese, M. (2003). Stress in organizations. In W. C. Borgman, D. R. Ilgen, R. J. Klimoski, \& I. B. Weiner (Eds.), Handbook of psychology: Industrial and organizational psychology (Vol. 12, pp. 453-491). Hoboken: John Wiley \& Sons.

Tepas, D. I., \& Price, J. M. (2001). What is stress and what is fatigue? In P. A. Hancock \& P. A. Desmond (Eds.), Stress, workload and fatigue (pp. 607-622). Boca Raton, FL: CRC Press.

Van Dongen, H. P. A., Maislin, G., \& Dinges, D. F. (2004). Dealing with inter-individual differences in the temporal dynamics of fatigue and performance: Importance and techniques. Aviation Space and Environmental Medicine, 75(3), A147-A154. Retrieved from https://pubmed.ncbi.nlm.nih.gov/15018277/

Vasconcelos, F. C. de, Vasconcelos, I. F. G. de, \& Crubellate, J. M. (2008). Stress in organizations: Between efficiency and the institutionalization of fear. BAR - Brazilian Administration Review, 5(1), 37-52. https://doi.org/10.1590/s1807-76922008000100004

Vasconcelos, S. P., Fischer, F. M., Reis, A. O. A., \& Moreno, C. R. de C. (2011). Fatores associados à capacidade para o trabalho e percepção de fadiga em trabalhadores de enfermagem da Amazônia ocidental. Revista Brasileira de Epidemiologia, 14(4), 688-697. https://doi.org/10.1590/S1415-790X2011000400015

Voorhees, C. M., Brady, M. K., Calantone, R., \& Ramirez, E. (2016). Discriminant validity testing in marketing: An analysis, causes for concern, and proposed remedies. Journal of the Academy of Marketing Science, 44(1), 119-134. https://doi.org/10.1007/s11747-015-0455-4

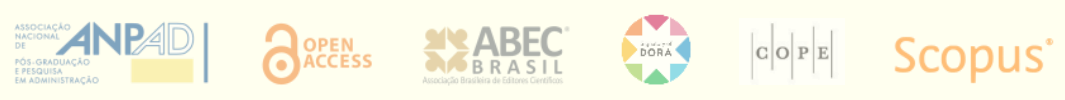


Wimalasiri, J. S. (1995). An examination of the influence of human resource practices, organizational commitment and job satisfaction on work performance. International Journal of Management, 12(3), 352-363.

Winwood, P. C., Winefield, A. H., Dawson, D., \& Lushington, K. (2005). Development and validation of a scale to measure work-related fatigue and recovery: The occupational fatigue exhaustion/recovery scale (OFER). Journal of Occupational and Environmental Medicine, 47(6), 594-606. https://doi.org/10.1097/01.jom.0000161740.71049.c4

Yoshitake, H. (1971). Relations between the symptoms and the feeling of fatigue. Ergonomics, 14(1), 175-186. https://doi.org/10.1080/00140137108931236

Yoshitake, H. (1978). Three characteristic patterns of subjective fatigue symptoms. Ergonomics, 21(3), 231-233. https://doi.org/10.1080/00140137808931718

Zaslona, J. L., O’Keeffe, K. M., Signal, T. L., \& Gander, P. H. (2018). Shared responsibility for managing fatigue: Hearing the pilots. PLOS ONE, 13(5), e0195530. https://doi.org/10.1371/journal.pone.0195530

\section{Author contributions}

$1^{\text {st }}$ author: conceptualization (lead), formal analysis (lead), methodology (lead), validation (equal), writing-original draft (lead), writing-review \& editing (lead).

$2^{\text {nd }}$ author: conceptualization (equal), supervision (equal), validation (equal), writing-review \& editing (equal).

$3^{\text {rd }}$ author: conceptualization (equal), resources (lead), validation (equal), writing-review $\&$ editing (equal).

\section{Authors}

Victor Rafael Rezende Celestino*

Universidade de Brasília, Faculdade de Administração, Contabilidade Economia, e Gestão Pública

Campus Darcy Ribeiro, Prédio da FACE, Asa Norte, 70910-900, Brasília, DF, Brazil

vrcelestino@unb.br

(iD) https://orcid.org/0000-0001-5913-2997

Julia Sursis Nobre Ferro Bucher-Maluschke

Universidade Brasília, Programa de Pós-Graduação em Psicologia Clínica e Cultura

Campus Universitário Darcy Ribeiro, ICC Ala Sul, Bl. A, Sala AT 028/7, 70910-900, Brasília, DF, Brazil

psibucher@gmail.com

(iD) https://orcid.org/0000-0002-9194-8993

\section{Elaine Cristina Marqueze}

Universidade Católica de Santos, Centro de Ciências Sociais Aplicadas e da Saúde (CCSAS)

Av. Conselheiro Nébias, no 589/595, Boqueirão, 11015-002, Santos, SP, Brazil

ecmarqueze@gmail.com

(iD) https://orcid.org/0000-0002-4987-7757

* Corresponding author

Peer review is responsible for acknowledging an article's potential contribution to the frontiers of scholarly knowledge on business or public administration. The authors are the ultimate responsible for the consistency of the theoretical references, the accurate report of empirical data, the personal perspectives, and the use of copyrighted material.

This content was evaluated using the double-blind peer review process. The disclosure of the reviewers' information on the first page is made only after concluding the evaluation process, and with the voluntary consent of the respective reviewers.

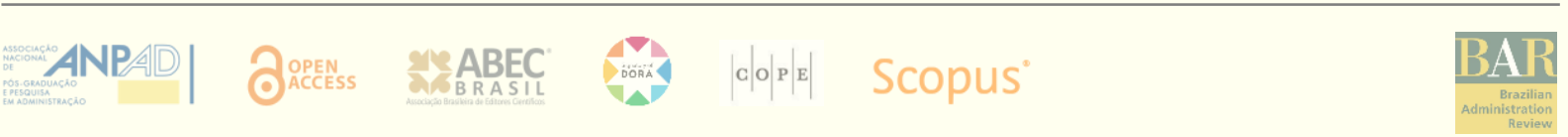

